\title{
THE HISTORY OF THE ROCK GARDEN AT THE ROYAL BOTANIC GARDEN EDINBURGH
}

\author{
Robert Unwin ${ }^{l}$
}

\section{ABSTRACT}

The Rock Garden at the Royal Botanic Garden Edinburgh is well known and loved by alpine plant enthusiasts worldwide. This paper describes the history of the area since 1809 when it was established as the demonstration garden for the Caledonian Horticultural Society. It describes the change in horticultural fashions and techniques for growing and displaying plants, and the role that influential horticulturists have played in the history of the Garden. The paper is illustrated with maps and photographs taken throughout the period.

\section{INTRODUCTION}

Today the south-eastern corner of the Royal Botanic Garden Edinburgh (RBGE) is home to the Rock Garden and its large collection of alpine plants. This area came under the ownership of RBGE in 1864. However, associations with RBGE predate this because from 1823 the area was owned by the Caledonian Horticultural Society (now Royal Caledonian Horticultural Society) and was known as the Experimental Garden. Thus there are two phases to the history as a garden and designed landscape: "pre-Rock Garden' and then its development as the Rock Garden. Within this latter phase there have been many changes both in the plants grown and in the styles of design and horticulture employed to cultivate and display them. The Rock Garden has exemplified these and been at the heart of the activities of some of the most influential horticulturists in Scotland since 1823 .

\section{THE CALEDONIAN HORTICULTURAL SOCIETY AND THE EXPERIMENTAL GARDEN}

In 1809 the inaugural meeting of the Caledonian Horticultural Society (CHS) took place; their objective was the "encouragement and improvement of the best fruit, the most choice flowers and most useful culinary vegetables" (Buxton, 2012). In 1823 the Society secured the lease of 4 ha at Inverleith, a district within Edinburgh, from James Rocheid who resided at Inverleith House and owned the surrounding lands (Fletcher \& Brown, 1970). The Botanic Garden was the illustrious neighbour on the adjacent land and it was in the process of moving plants from its previous site on Leith Walk. RBGE

1. Robert Unwin is a Senior Horticulturist in the Alpine Department at the Royal Botanic Garden Edinburgh. Address: 20A Inverleith Row, Edinburgh EH3 5LR, UK.

Email: R.Unwin@rbge.org.uk 
had outgrown the Leith Walk site and in 1820 had also purchased around 6 ha from Rocheid.

The CHS became the Royal Caledonian Horticultural Society (RCHS) in 1824. The following year the Principal Gardener (a title equivalent to today's 'Curator') of the Botanic Garden, William McNab, developed a plan for the RCHS Experimental Garden. Areas were designated for propagation, roses, annual and perennial plants, and various kinds of fruit trees were cultivated. Their first Head Gardener/Superintendent, James Barnett, came from the Horticultural Society in London, and was succeeded in 1836 by James McNab, son of William McNab (Buxton, 2012). James McNab oversaw the 'golden years' of the RCHS; he was a talented fundraiser and made significant developments possible. In 1843, the construction of an impressive Exhibition Hall (Figs 1 \& 2) was completed which facilitated Society shows and meetings. In 1848, The Gardeners' Chronicle reported on a circular issued by the RCHS to develop a Winter Garden at their Experimental Garden site at Inverleith, stating: "if carried out to its full extent, [it] would undoubtedly confer on the lovers of flowers one of the greatest enjoyments which it is possible to conceive" (Gardeners' Chronicle, 1848).

If the plans the RCHS had for Edinburgh are compared to the Winter Gardens of Paris and London the article in the Chronicle illustrates the grandeur of the RCHS ambition to grow exotic plants. A number of hothouses comprising a quadrangular structure with a promenade inside were proposed. The Society's committee approved the Winter Garden, a structure $140 \times 35 \mathrm{ft}(42.5 \times 10.5 \mathrm{~m})$, the design of which is credited to Drummond of Canonmills with probable input from James McNab (Fletcher \& Brown, 1970).

\section{CHANGING TIMES - ACQUISITION BY THE ROYAL BOTANIC GARDEN EDINBURGH}

In 1850, the management of the Experimental Garden and the realisation of the Winter Garden within it became a financial burden for the RCHS. The Society's circumstances changed dramatically when William McNab died in 1849. The RCHS simultaneously lost one of its most important supporters and arguably its most important employee with son James McNab moving to the Botanic Garden to succeed his father. Membership of the Society was in a period of decline, causing further difficulties (Buxton, 2012). In 1864 , one year after its 40th anniversary, the RCHS could no longer afford to maintain the Experimental Garden and so it was incorporated into the Botanic Garden and was gifted to RBGE by the government in lieu of debts. The intention was to develop it as an arboretum (Gardeners' Chronicle, 1869).

Details of the Experimental Garden can be seen in a map of the area from the 1820 s to 1860 s. Fig. 1 shows the area before the first Rock Garden was developed. The exact survey date for the map is unclear although the inclusion of the structure for the Winter Garden/Conservatory (circled) suggests that it was some time after 1850. The Superintendent's Cottage and the Society's Exhibition Hall are annotated, as are areas 


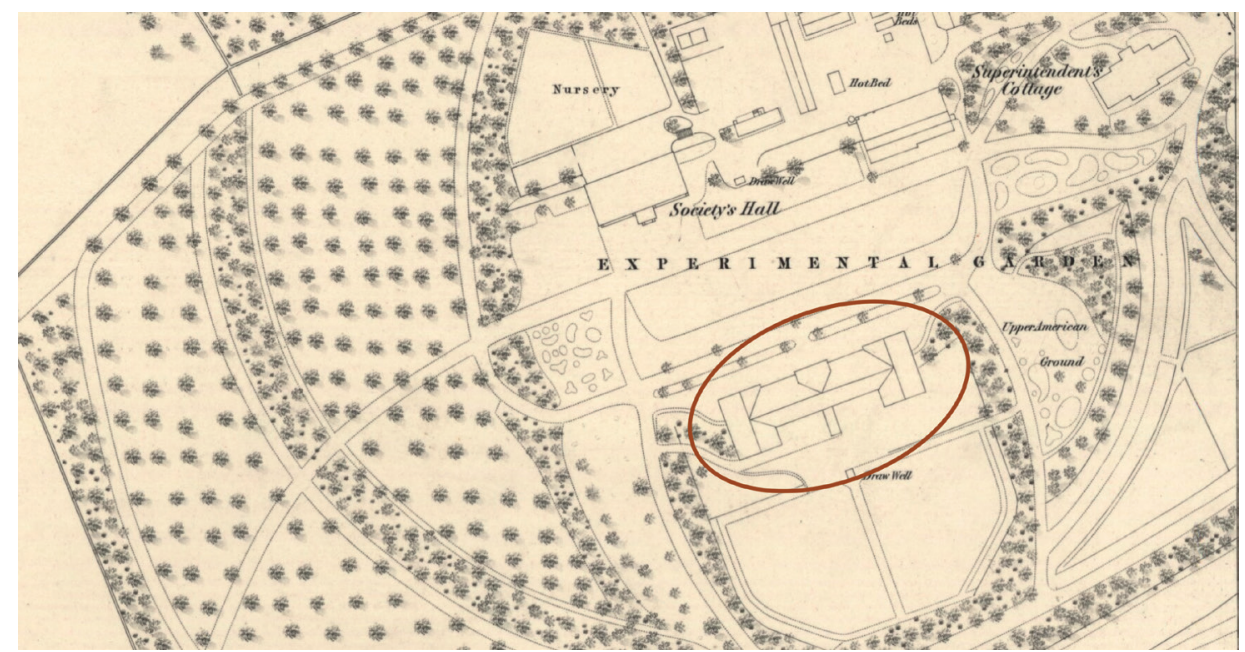

Fig. 1 Ordnance Survey town plan of Edinburgh, 1849-1853.

devoted to the cultivation of 'American Plants', annotated Upper and Lower American Ground. Fig. 2 shows the Society's Exhibition Hall and its surroundings.

\section{THE INFLUENCE OF THE MCNABS - WILLIAM AND JAMES}

Ayrshireman William McNab (1780-1848) was employed by the Royal Botanic Gardens, Kew when he was 20 years old. In 1810, he moved to Edinburgh to take up the post of Principal Gardener of RBGE. His son James (Fig. 3) followed in his footsteps. By the age of 12, James was working as an apprentice gardener at RBGE. On completion of his apprenticeship James remained as a journeyman then became a foreman to his father. In 1834, he left Edinburgh, travelling to North America with nurseryman Robert Brown (Hardy, 2011) before returning in 1836 to become Head Gardener and Superintendent for the RCHS. In 1849, he returned to RBGE where he oversaw immense change as the Garden more than doubled in size. In 1864, RBGE acquired the Experimental Garden and in 1877 it acquired the grounds of Inverleith House. James McNab is most closely associated with the creation of the Rock Garden (Fletcher \& Brown, 1970).

In $1871 \mathrm{McNab}$ wrote an article in The Gardeners' Chronicle explaining the construction of the Rock Garden, in which he explained: "Some years ago the removal of a high wall which separated the Botanical Garden from the old Experimental Garden here became necessary, to throw the two establishments into one. To utilize this large portion of old building material I commenced what I call a Rock Garden" (McNab, 1871).

Additional stone for construction was sourced from Hailes Quarry near Edinburgh (McNab, 1878); other blocks of stone were taken from dismantled buildings in 


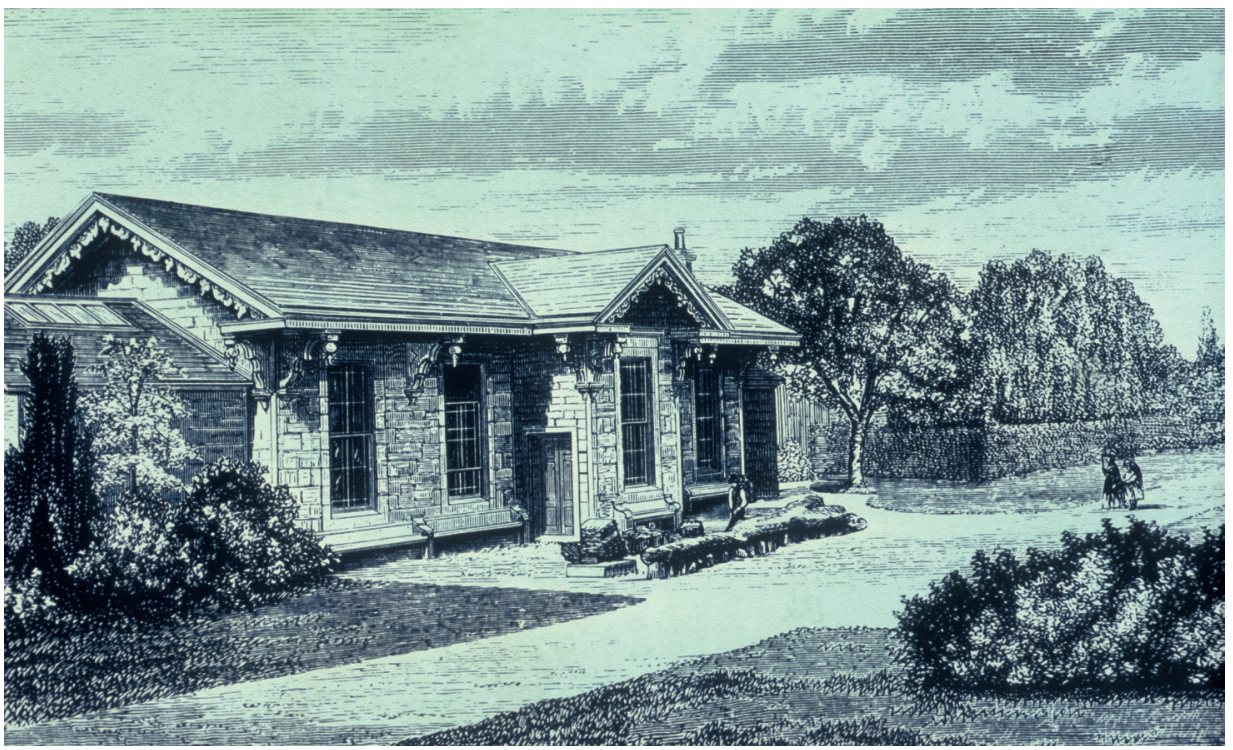

Fig. 2 Engraving of the RCHS Exhibition Hall showing further extensions which were added c. 1860. It appears to feature the fossil tree from the quarry at Craigleith, Edinburgh. This is now beside the Temperate Palm House at RBGE. Image: RBGE Archives.

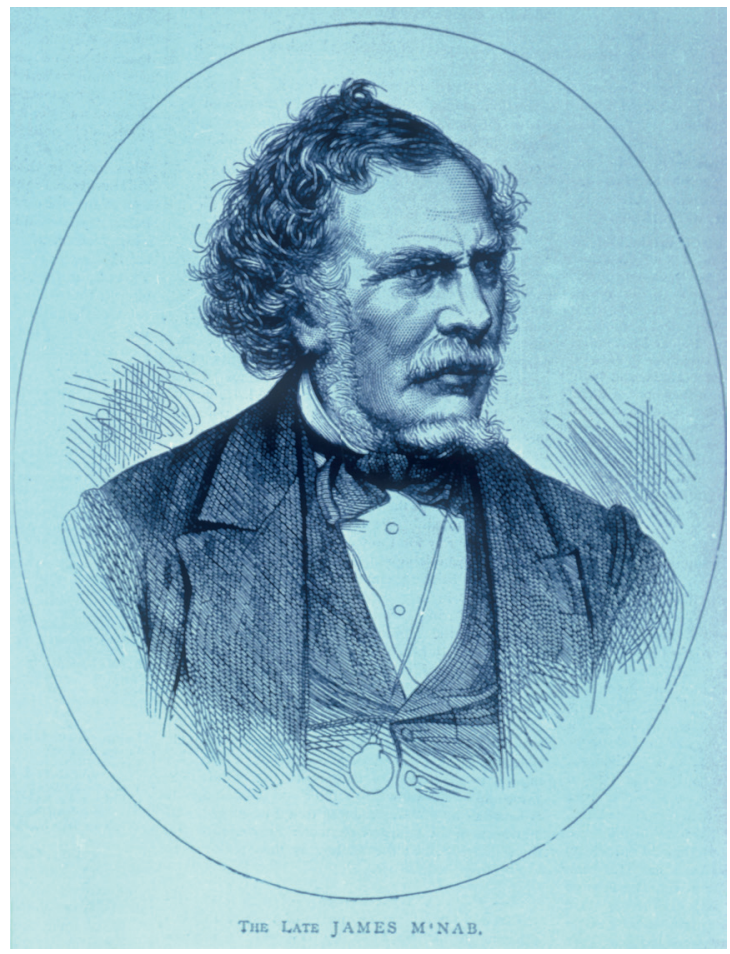

Fig. 3 James McNab. Image: RBGE Archives. 
Edinburgh and even basalt columns on Staffa and the Giant's Causeway (Paterson, 2013). These are apparent in the foreground of Fig. 9.

The earliest reference to the Rock Garden at RBGE is from a newspaper article in the Edinburgh Evening Courant, 18 April 1870, by Adam White, a regular contributor to the paper on aspects of natural history who comments on the area (Hardy, 2014) (Fig. 4).

Another detailed Ordnance Survey map of the area was produced in 1876-1877 (Fig. 5) and shows clearly the changes which were made in the 25 years since the map in Fig. 1 was drawn. The northern boundary between the Botanic Garden and the Experimental Garden has disappeared as RBGE has incorporated the area previously owned by the RCHS. The Society's Hall is now noted as the Herbarium and many of the smaller buildings shown in previous maps have been demolished. The Winter Garden/ Conservatory is now annotated, but of greatest interest is, to the south of this, the first map evidence of a Rock Garden on the site.

Looking at this map in conjunction with contemporary photographs of the site alongside McNab's writings, many of the details of his Rock Garden can be identified. The sections, steps and paths separating areas can be identified. The 1876 map (Fig. 5) reveals much of the detail of the Rock Garden landscape that McNab created so it is possible to approximate where historic photographs held in the RBGE Archives were taken by comparing this map with images of the Rock Garden.

Fig. 6 is one of the earliest images of the Rock Garden. It appears to have been taken from the Winter Garden/Conservatory stairway looking centrally onto the Rock Garden. The yellow arrow in Fig. 5 indicates the position from which the photograph was taken. It gives an impression of the sectional layout of the overall area of the Rock Garden. A number of small mounds topped with an Araucaria can be seen in the photograph corresponding to those on the map in Fig. 5. McNab named each of these mounds after a famous alpine botanist (Paterson, 2013).

Fig. 7 is a very recent discovery from the RBGE's Archive; it shows an elevated view of the Rock Garden with McNab's characteristic compartments and Araucaria on the mounds clearly visible. The black arrow on Fig. 5 indicates the position from which this photograph was taken, looking in a south-easterly direction. The most remarkable thing about this image is that the man standing surveying the Rock Garden right of centre is believed to be James McNab. Close examination of the image has shown a remarkable likeness between this man and the portrait of McNab in Fig 3.

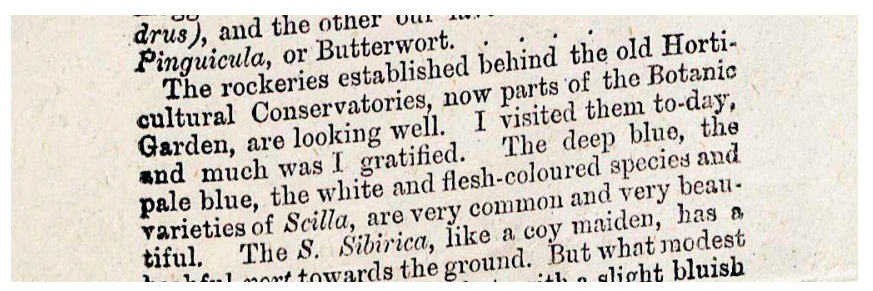

Fig. 4 Extract from an article by Adam White in the Edinburgh Evening Courant, 18 April 1870. 


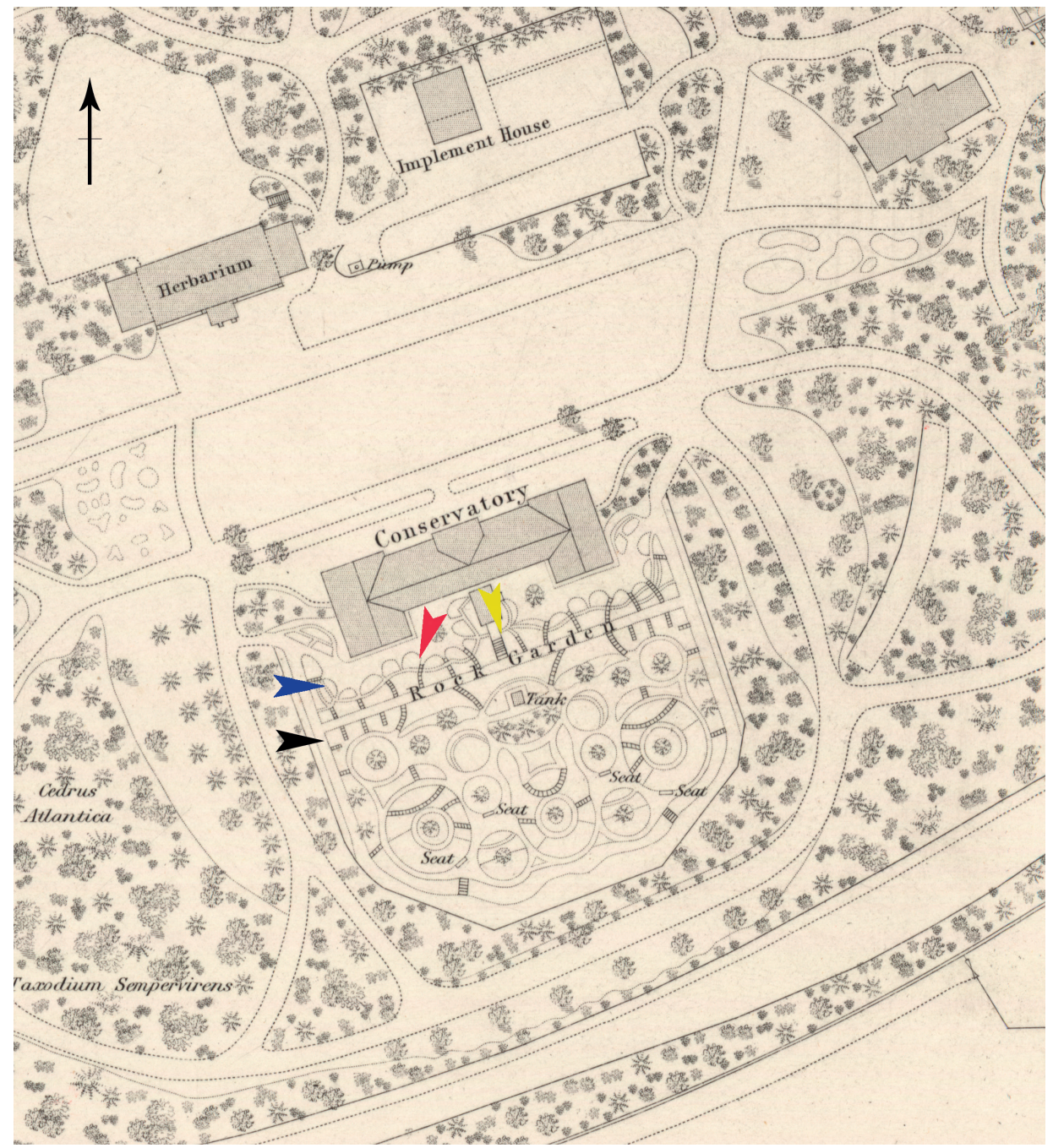

Fig. 5 Large-scale Ordnance Survey Scottish town plan of Edinburgh, 1876.

Map evidence suggests that Fig. 8 is taken from where the red arrow is positioned on Fig. 5. Looking in a south-westerly direction, the scalloped edge to the foreground and the immediate narrow stone/brick path can be identified. Again, the characteristic compartments are also visible. McNab stated that the alpine plants thrived in the Rock Garden and he never regretted transferring the pot-grown alpines here: "It was often a difficult matter to get such a large collection of alpine plants as existed here in proper order, particularly when confined under pot culture, the attention necessary for shifting such a collection being often more than it was possible to undertake at the proper season with a limited staff of men. Unless such re-potting was regularly gone into, the foliage and flowers of each could not properly develop. In this state species often got 


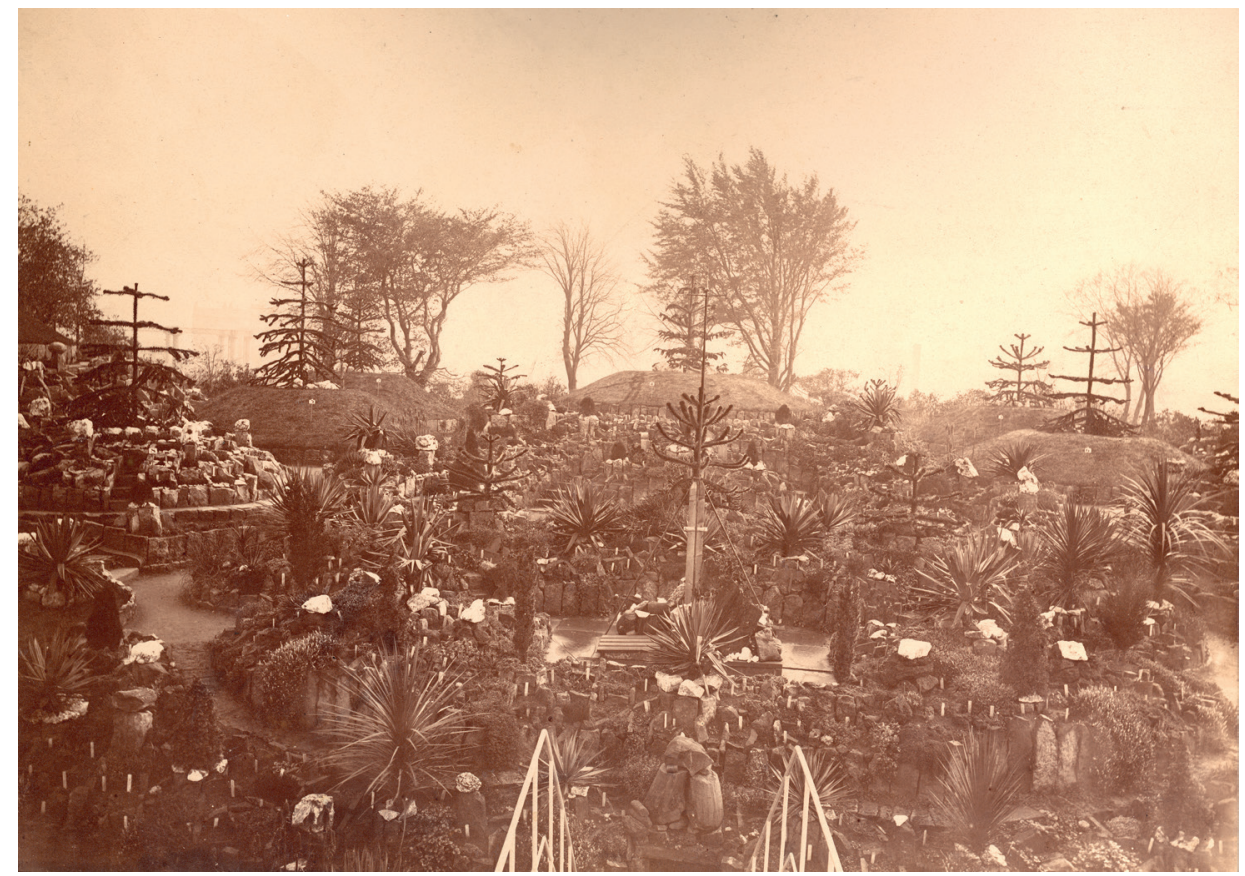

Fig. 6 A central view of James McNab's Rock Garden, c. 1876. Image: RBGE Archives.

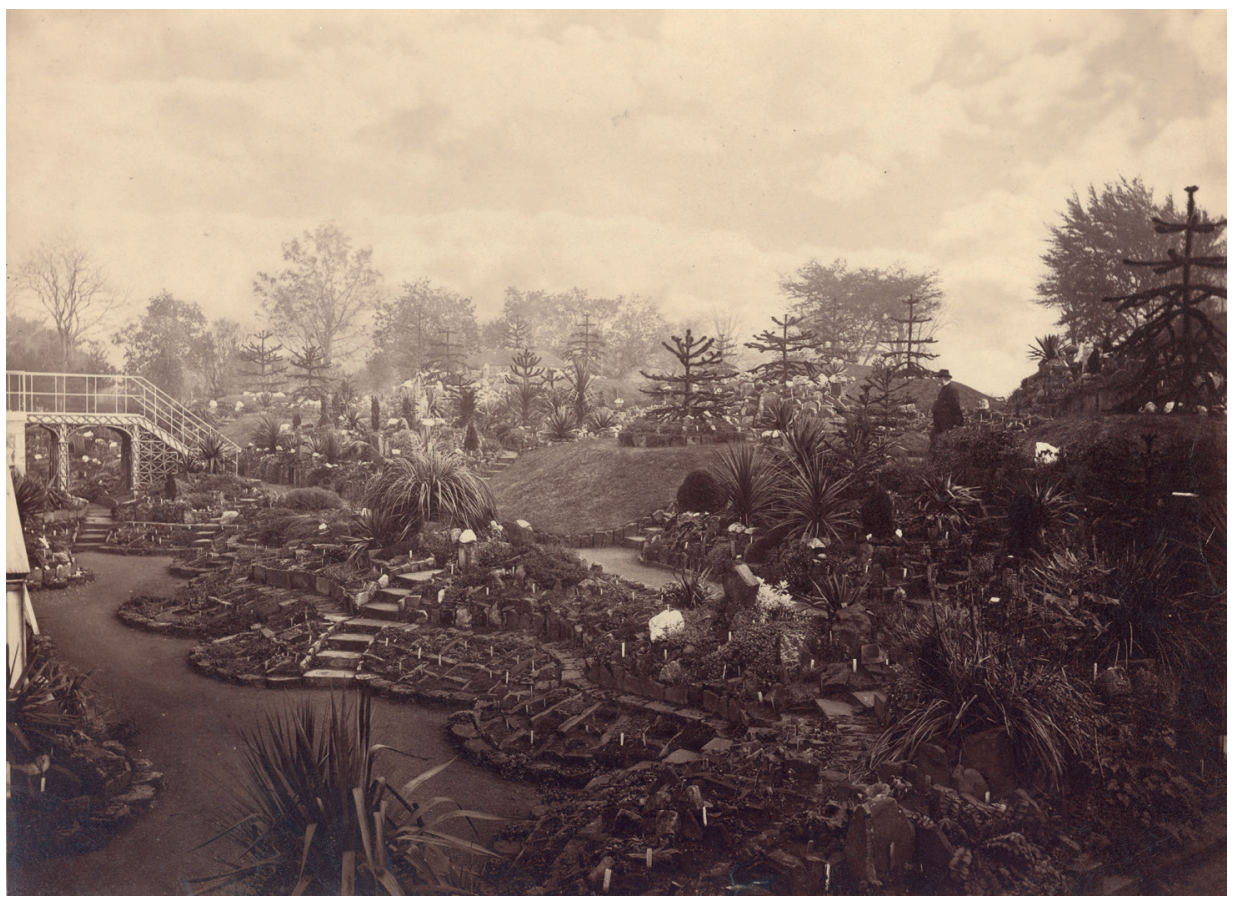

Fig. 7 James McNab surveying his Rock Garden, c. 1877. Image: RBGE Archives. 


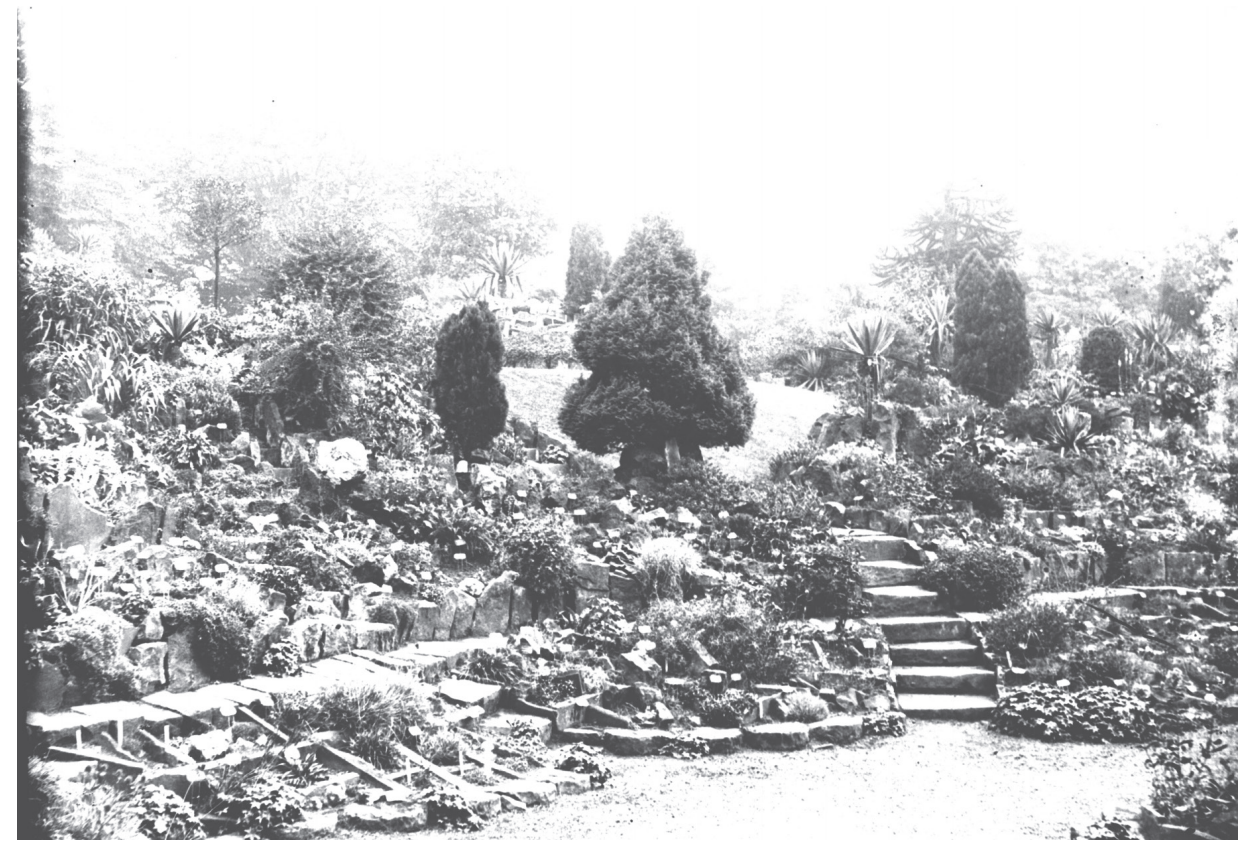

Fig. 8 Photograph of James McNab's Rock Garden, c. 1890. Image: RBGE Archives.

confounded together, which is not likely to be the case when all are planted in separate rock-work compartments" (McNab, 1871).

Undoubtedly McNab's first concern in the Rock Garden was creating ideal growing conditions; however he also took some interest in colour and aesthetics. Around half of the compartments were filled with alpines, along with dwarf shrubs and herbaceous species. The others served a different purpose:

"The remaining compartments are filled with free-flowering duplicates, placed at uniform distances to please the eye of those whose taste is more colour; but even to the botanical cultivator, such free flowering duplicate masses cannot be otherwise than extremely interesting.

"In the construction of the Rock Garden here, I got the stones of the old wall [the separating wall between the Experimental Garden and the RBGE sites] just alluded to split up longitudinally, and arranged in a piece of sloping ground facing the north, which I had previously laid out in an undulating and somewhat geometric form, and which I had divided into uniform sections, separated by stone paths and steps. These sections were then divided into angular compartments of various sizes, and each filled with soils suited for the various plants to be put in them" (McNab, 1871). 
$\mathrm{McNab}$ took great care to create these compartments, explaining in detail their construction in an article in The Garden in 1878, in which he commented on how happy he was with the results of his experimental way of growing alpine plants in the Rock Garden. He planted sections in the Rock Garden in a variety of ways. Some were planted with alpines in geographical areas, similar to current phytogeographical plantings in the present Rock Garden. McNab's rationale for planting other sections was along similar 'order' plantings, common in botanic gardens at the time, where different species of the same genus were planted. He writes about specific sections of Sempervivum, Sedum, Saxifraga, Primula, Silene, Aubretia, Gentiana and Androsace. Some areas were planted with taxonomy in mind while others were planted because the plants were of similar heights. In 1871, McNab explained his treatment of compartments where springflowering bulbs were planted. After flowering, many of these species begin quickly to look untidy before dormancy. His solution was to cut them back and top-dress the compartment with a little soil, using shallow-rooted summer-flowering herbaceous or dwarf annuals to fill the gaps, extending interest in the Rock Garden: "Large divisions are also appropriate for a selection of monocotyledonous plants, exclusive of bulbs, such as dwarf and herbaceous species of Iris and Yucca; also species of Cordyline, Sporaxis, Helonias, Ophiopogon, Trillium, terrestrial orchids, Convallaria, Uvularia, Narthecium, Tofieldia, Acorus, rare species of alpine Carex etc" (McNab, 1871).

Over 4,000 compartments were created in the Rock Garden; by 1871, around 2,200 were filled with alpine plants transferred from the RBGE collection of pot-grown alpines. So many compartments resulted in a range of different aspects and by using different soil mixes different conditions were created to suit alpine and dwarf herbaceous plants (McNab, 1871).

The blue arrow in Fig. 5 indicates the likely position where Fig. 9 was taken. Looking in a south-easterly direction the stairway from the Rock Garden to the Winter Garden can be identified. The landscape structure has changed little since the images were taken; however, the plantings have matured with only one of the Araucaria trees of earlier images remaining in this image, suggesting their removal at some point in the late 19th century. This species is a strange choice for inclusion in the planting scheme and was perhaps inspired by the Victorian fascination for conifers. They certainly added to the artificiality of the area.

\section{THE BALFOURS: JOHN HUTTON AND ISAAC BAYLEY}

"[This] construction of McNab's presents a remarkable appearance and one wonders how it could possibly been conceived. It was nevertheless to become one of the Botanic Garden's greatest assets" (Fletcher \& Brown, 1970).

John Hutton Balfour (1808-1884) (Fig. 10) was Regius Keeper for McNab's entire time at the Garden. A year after McNab's death, Balfour left RBGE, retiring in 1879. Alexander Dickson (1836-1887) was appointed to succeed him and John Sadler (18371882) replaced McNab as Curator (Rae, 2011). During their regime little is recorded 


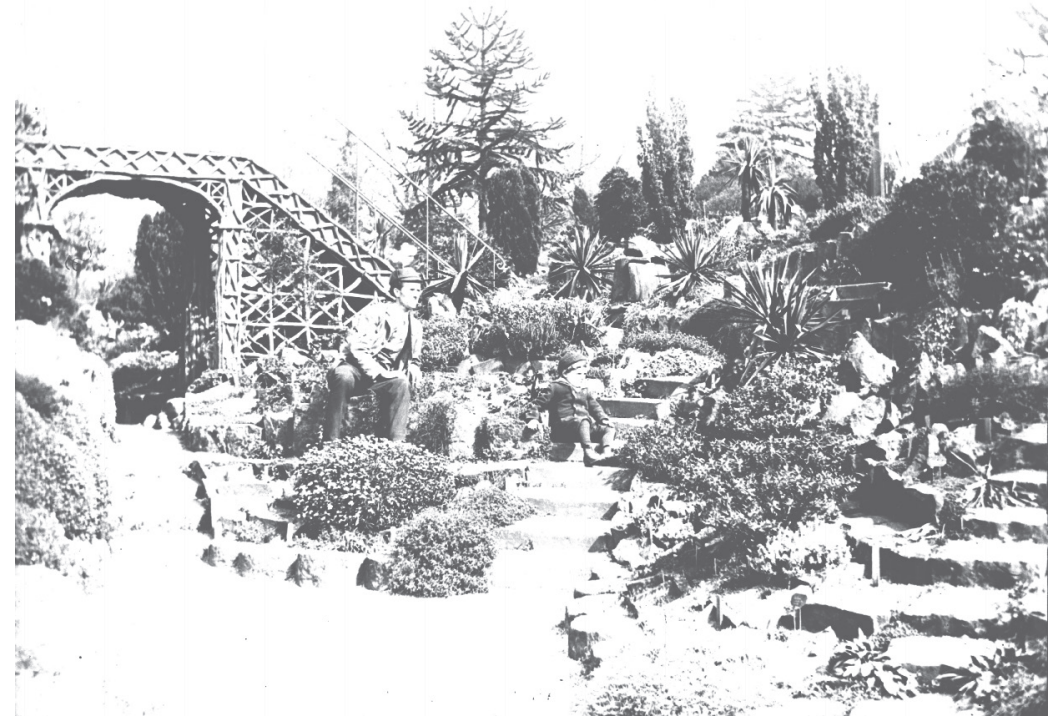

Fig. 9 Photograph of James McNab's Rock Garden looking east, c. 1894, showing the ornamental stairway leading to an elevated viewing point and the Winter Garden. Image: RBGE Archives.

regarding changes to the Rock Garden. An exception was the creation of new areas of grass and the addition of huge conical mounds covered with turf, planted with some of McNab's favourite conifers (Munro, 1882). These, the writer states, "create a landscape of miniature hills and glens where Heaths, Andromedas, Kalmias and Menziesias grow to perfection". However, not everyone agreed, and the Rock Garden had its critics.

"The Rock Garden ... is most miserable as regards to its effect - extremely like cockney tea gardens and childish sticking together of clinkers and bad bricks. Artistically, it is about the most tormenting thing I have ever seen for many a long day ... The countless pockets and wrinkles harbour vermin, and prevent any free grouping of pretty plants together" (Comment by 'Traveller' in The Garden, 30 September 1882).

The counter-argument appeared in an issue dated 28 October from Max Leichtlin, who comments that "introduction, trial and conservation of plants should rank foremost and artistic grouping come only as a secondary matter ... I admit that pockets on rockwork would not be admissible in a private garden where plants are grown simply from enjoyment" (Leichtlin, 1882).

In 1887, Isaac Bayley Balfour (Fig. 12), Hutton Balfour's son, became Regius Keeper. Two years into his employment an HM Treasury committee was set up to consider the Regius Keeper's role and future funding of RBGE. One recommendation was that the Camellia House be demolished as it was beyond economic repair, suggesting its removal would facilitate a Rock Garden extension (Fletcher \& Brown, 1970). In 1871, McNab stated that the Rock Garden was "still in progress of extension". 


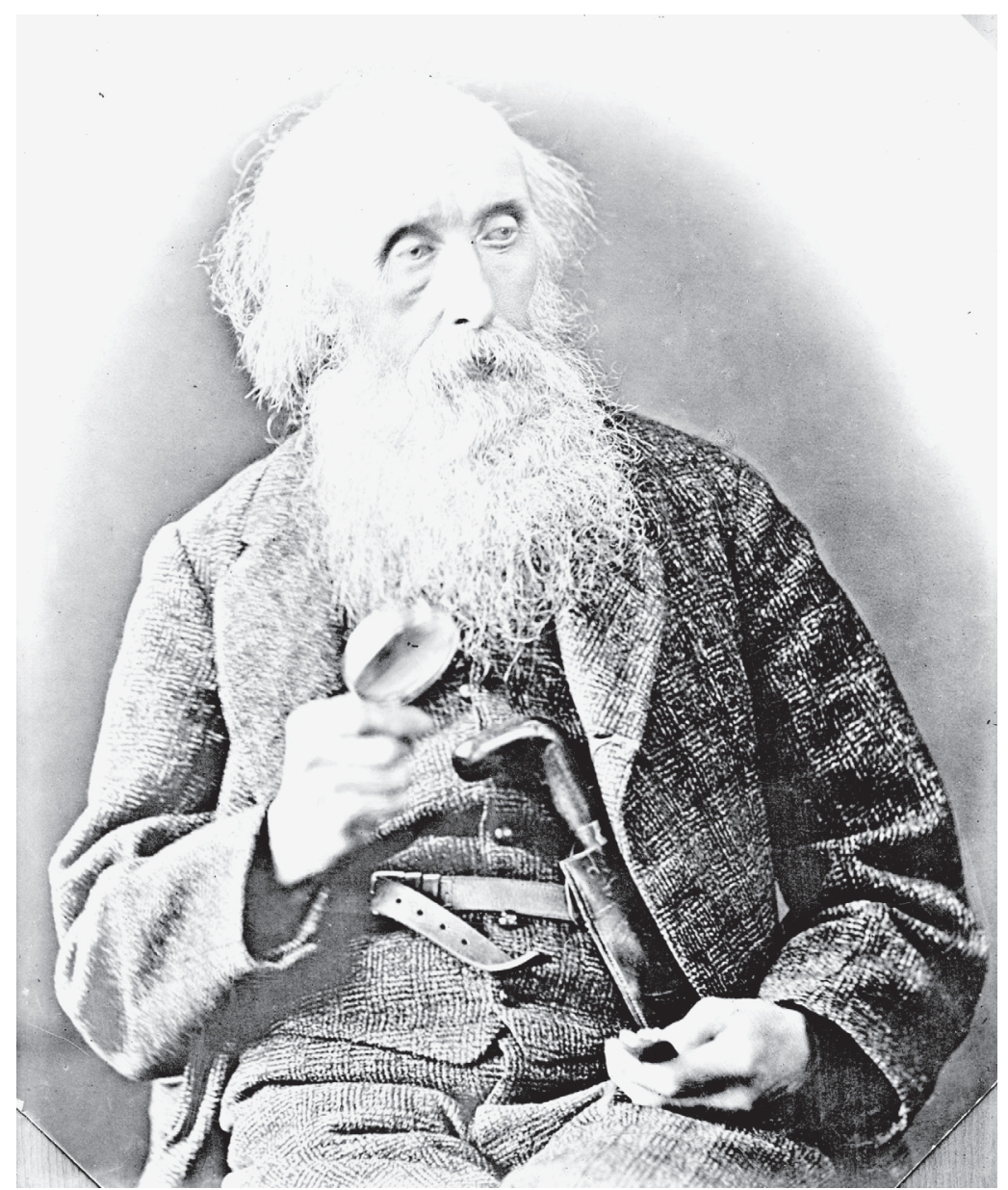

Fig. 10 John Hutton Balfour. Image: RBGE Archives.

At this time it was $190 \mathrm{ft}$ in length by $85 \mathrm{ft}$ wide $(58 \times 26 \mathrm{~m})$ with a height of $12 \mathrm{ft}$ $(3.6 \mathrm{~m})$. Ultimately he planned a final size of $120 \mathrm{ft}(36.6 \mathrm{~m})$ wide by $18 \mathrm{ft}(5.5 \mathrm{~m})$ high (Fletcher \& Brown, 1970).

The Rock Garden remained around this size until Bayley Balfour's arrival: "it [McNab's Rock Garden] was not entirely pleasing to Balfour, who from time to time reconstructed part of the rockwork with the aim of abolishing many of the small pockets which had been for so long in use, and using much larger and more irregular rocks" (Fletcher \& Brown, 1970).

Expansion of the Rock Garden allowed Bayley Balfour to remove some of the small compartments McNab had favoured but it was another man, not a member of RBGE staff, who proved to be the catalyst for dramatic changes to the Rock Garden. Yorkshireman Reginald Farrer was a passionate alpine plantsman, an authority on rock 
gardens and an opinionated garden critic (Fig. 11). Farrer spent eight months in Japan in 1902 where the influences of Japanese gardening styles and their long tradition of rock gardening wore off on him. He was of the opinion that when designing a rock garden "naturalism superseded formal artificiality and where alpine plants were to grow in surroundings which, though ordered by man, copied as far as possible their original habitats" (Hobson, 1992).

\section{THE REGINALD FARRER EFFECT}

It is no surprise that Farrer had strong views on the Victorian artificially compartmentalised Rock Garden at RBGE: "The plan is simplicity itself. You take a hundred or a thousand cart loads of bald, square-faced boulders. You next drop them all about anyhow; and you then plant amongst them. The chaotic hideousness of the result is something to be remembered with shudders ever after" (Farrer, 1907).

These comments appeared in his book My Rock Garden (1907), when discussing the types of rock garden commonly found in Britain. Identifying three prevailing designs, he derogatorily classified them as the Almond Pudding, the Dog's Grave and the Devil's Lapful scheme, citing the Rock Garden at RBGE as the best example of the latter (Farrer, 1907).

On the Victorian era of horticulture Farrer was no more complimentary, describing it as "the grimmest deadly period ever struggled through by art and horticulture ... Everywhere there is formality without beauty, extravagance without value. The scarlet Pelargonium becomes the national flower" (Farrer, 1907).

Farrer's criticism of the Rock Garden was stinging but unsurprising considering that it was conceived at the height of the Victorian era and given his views generally on horticulture at this time. No evidence exists that it directly prompted the complete redevelopment of the Rock Garden; however, it was the likely catalyst for work which started the following year. Farrer and Bayley Balfour went on to work together. Farrer travelled widely in the Himalayas, collecting a large number of herbarium specimens and seeds for RBGE (Shulman, 2002). Several of these still survive in the Living Collection at RBGE (Cubey et al., 2012).

Redevelopment started in 1908, which saw McNab's construction of the preceding years completely dismantled; it continued until 1914 (Fletcher \& Brown, 1970). By this time the Rock Garden had been extended considerably and now covered almost 4 acres (1.6 ha). The design was much more natural in style than its predecessor that had been criticised by Farrer (Royal Botanic Garden Edinburgh, 1970). Fig. 13 shows the Rock Garden partway through the changes overseen by Bayley Balfour.

The redeveloped Rock Garden, however, was not without its critics: "At Edinburgh Botanic Gardens a rockery admirably constructed for the growth and display of plants has been removed in favour of one in which, as at Kew, stones appear essential, instead of plants" (Cowely, 1915).

Another opinion was that there was little to be seen in the redeveloped area except 


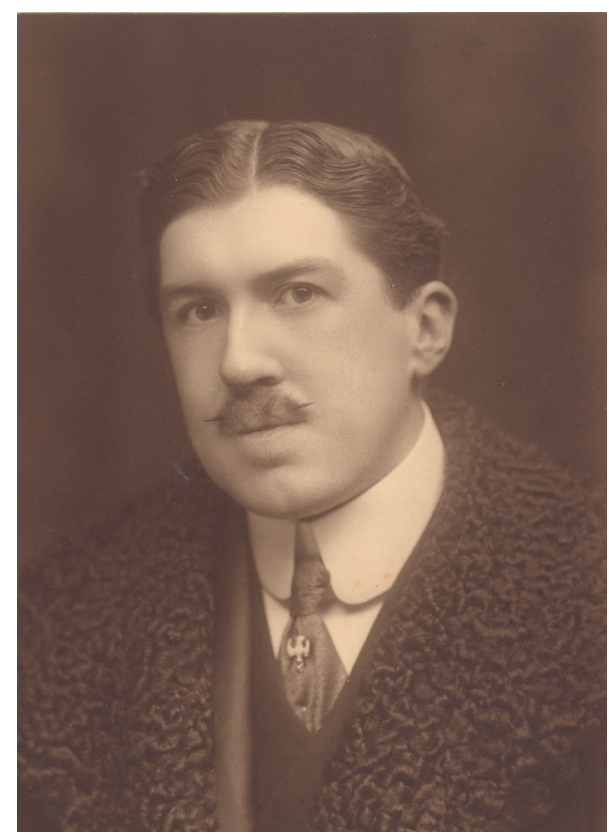

Fig. 11 Reginald Farrer. Image: RBGE Archives.

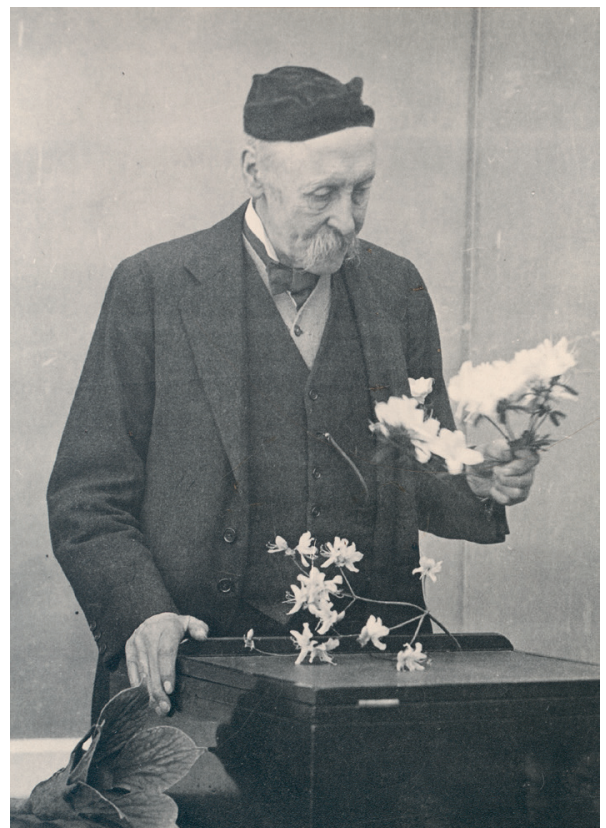

Fig. 12 Isaac Bayley Balfour. Image: RBGE Archives.

"huge masses of reddish rock, most of which must weigh over a ton each, so arranged as to give good scope for games of hide-and-seek among children" (Edina, 1912).

In Fig. 14 the extent of Bayley Balfour's redeveloped and expanded Rock Garden is clear. This image was taken from the area of the Rock Garden where the Winter Garden once stood looking towards the Society's Hall which then served as the Herbarium. The naturalistic design of the area is a complete transformation from McNab's time.

Further additions to the Rock Garden were made to accommodate alpines from the Sino-Himalaya, in which Bayley Balfour had developed a particular interest (Fletcher $\&$ Brown, 1970). In the 1920s a north-facing moraine was created specifically for these plants and Fig. 15 shows the addition of this feature to the landscape. It is annotated as 'Moraine' on the map (Fig. 17) but today is known as 'The Scree'.

The redeveloped and extended Rock Garden appears for the first time in an Ordnance Survey map in 1933; its appearance is very different from the Rock Garden shown in Fig. 5, being less formal and scattered with large rocks. It is described in the 1934 RBGE guide book as giving "the impression of a rugged mountain-side broken by miniature valleys ... large blocks are freely used" (RBGE, 1934).

A map produced in 1933 (not shown but very similar to Fig. 17) reveals many changes: the Winter Garden is not apparent because it was demolished in the early 1890s (Paterson, 2013). Adjacent areas to the Rock Garden are annotated as the Woodland Garden, and also visible on the southern edge of the Rock Garden is the Linnaeus 


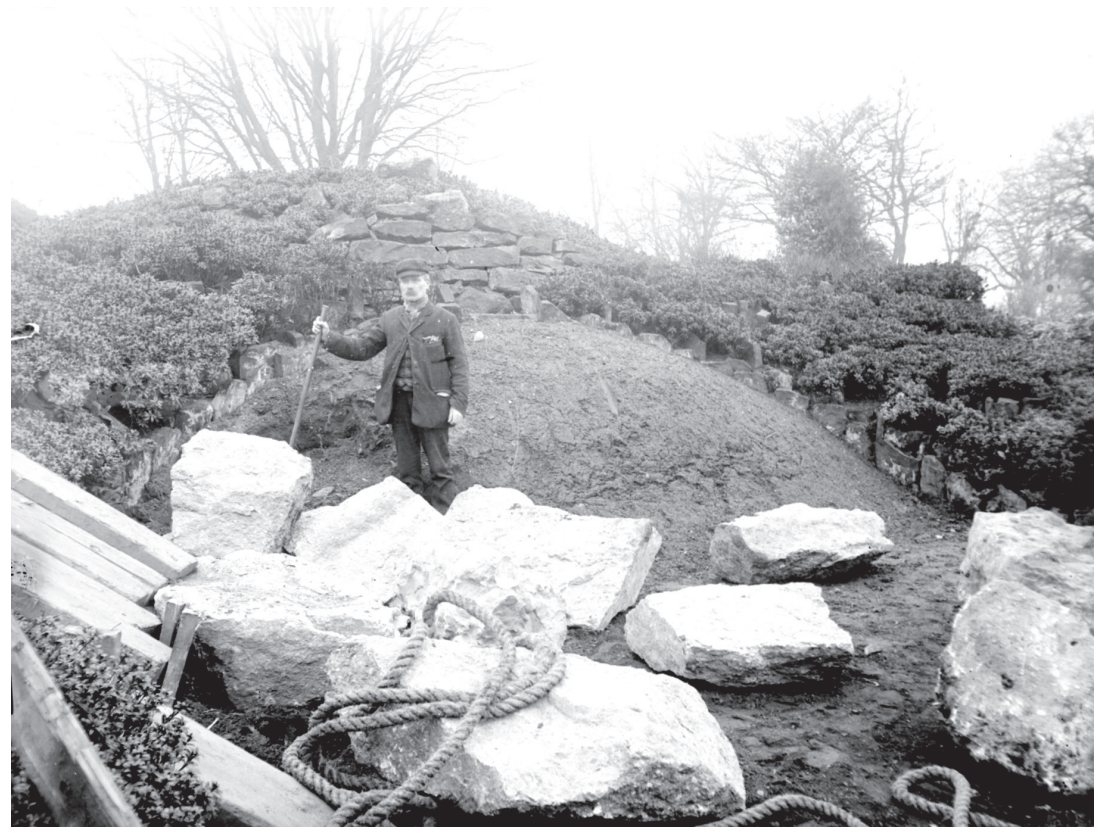

Fig. 13 Bayley Balfour's redevelopment of the Rock Garden using conglomerates from Ben Ledi and sandstone from Dumfriesshire, c. 1909. Image: RBGE Archives.

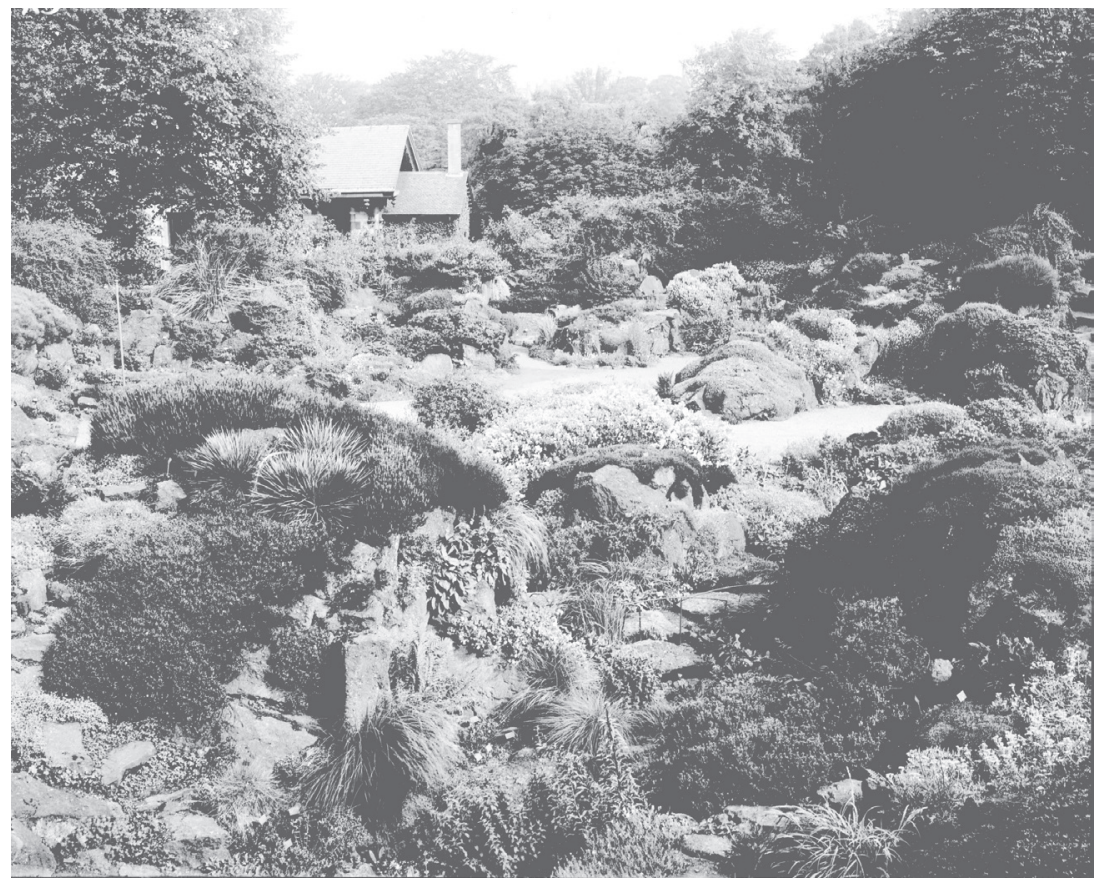

Fig. 14 The Rock Garden looking towards the Herbarium, c. 1920. Image: RBGE Archives. 


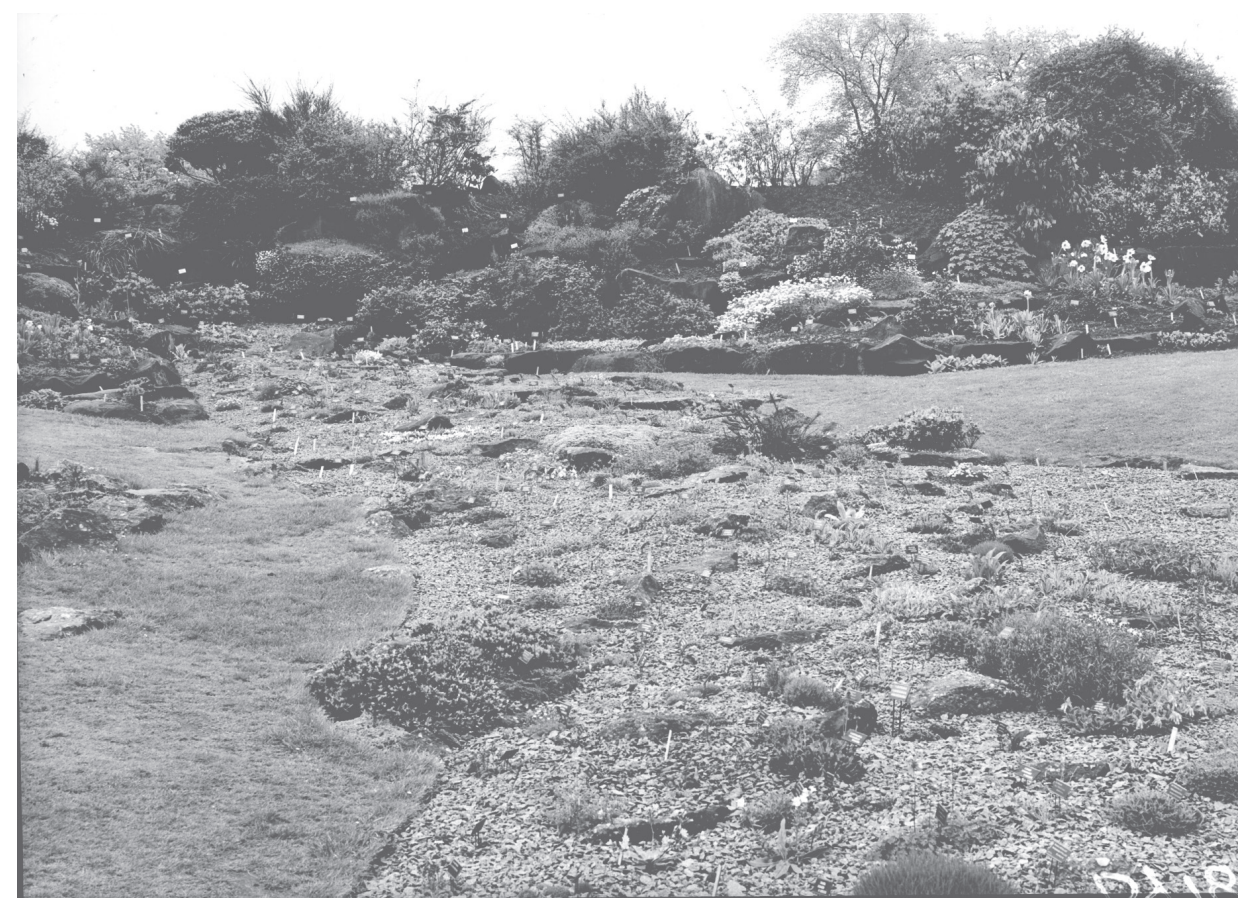

Fig. 15 The North Moraine, c. 1930, which still exists today. Image: RBGE Archives.

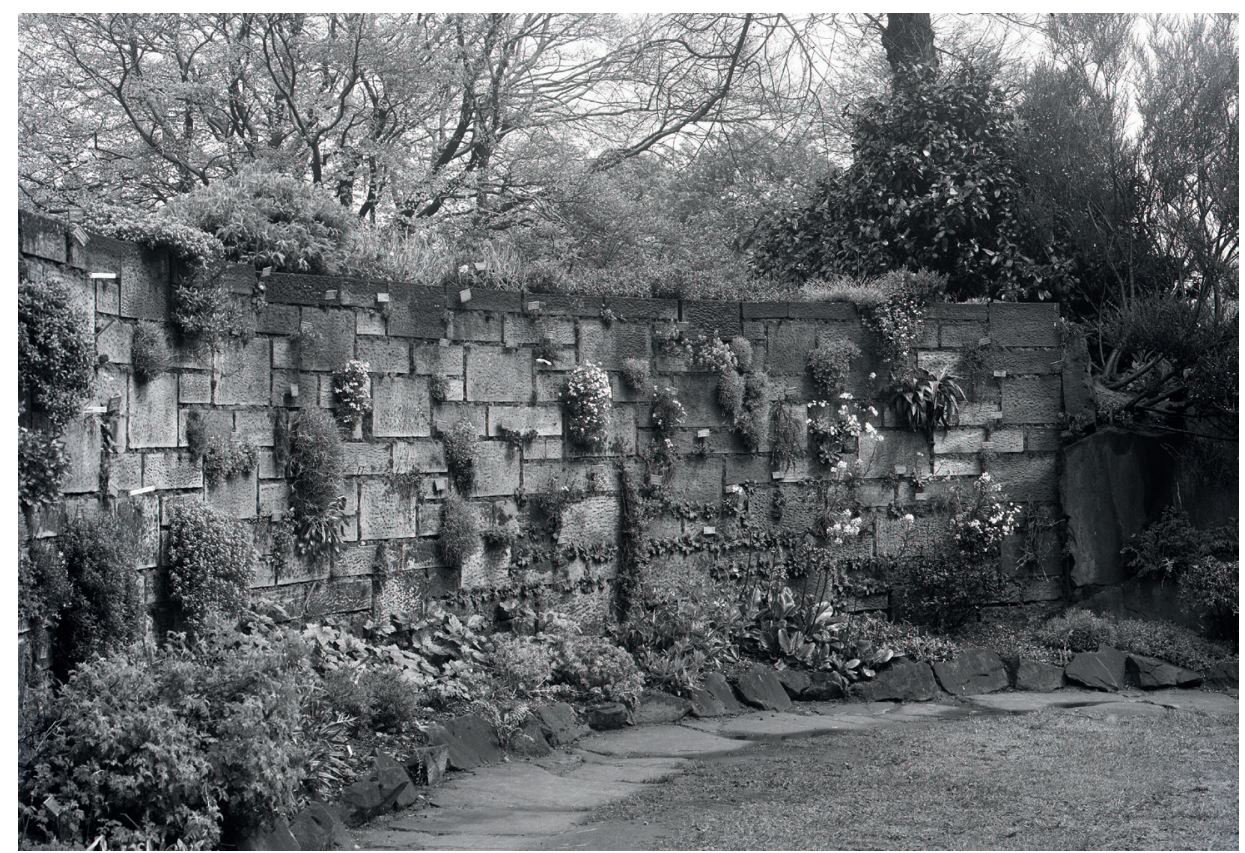

Fig. 16 A wall in the Rock Garden. Image: RBGE Archives. 
Monument. This is a large stone memorial to the Swedish botanist Carl Linnaeus (17071778). Today this is sited behind the main range of glasshouses and it may be relocated again after the completion of the Botanic Cottage reconstruction in 2015.

Within the Rock Garden, but not conforming to the more natural style, was a dressed red sandstone wall (Fig. 16). This was located between the South Moraine and Heath Garden annotated on Fig. 17. The guidebook produced in 1934 states that the vertical crevices in the wall are planted with Ramonda pyrenaica, Primula forrestii and Californian lewisias (RBGE, 1934). This wall is still featured in a map from 1958 (Fig. 17). However, Paterson (2012) states that the wall was removed in 1938.

Bayley Balfour died in 1922 and was replaced that same year by William Wright Smith (Rae, 2011). Under his stewardship the Rock Garden underwent several changes, most notably the addition of a South Moraine in 1937-1938. It survived for a short time but only remnants can be seen today. The area is now under grass with a narrow boundary planting of pine trees which shelters the Rock Garden (Fig. 18) (Fletcher \& Brown, 1970).

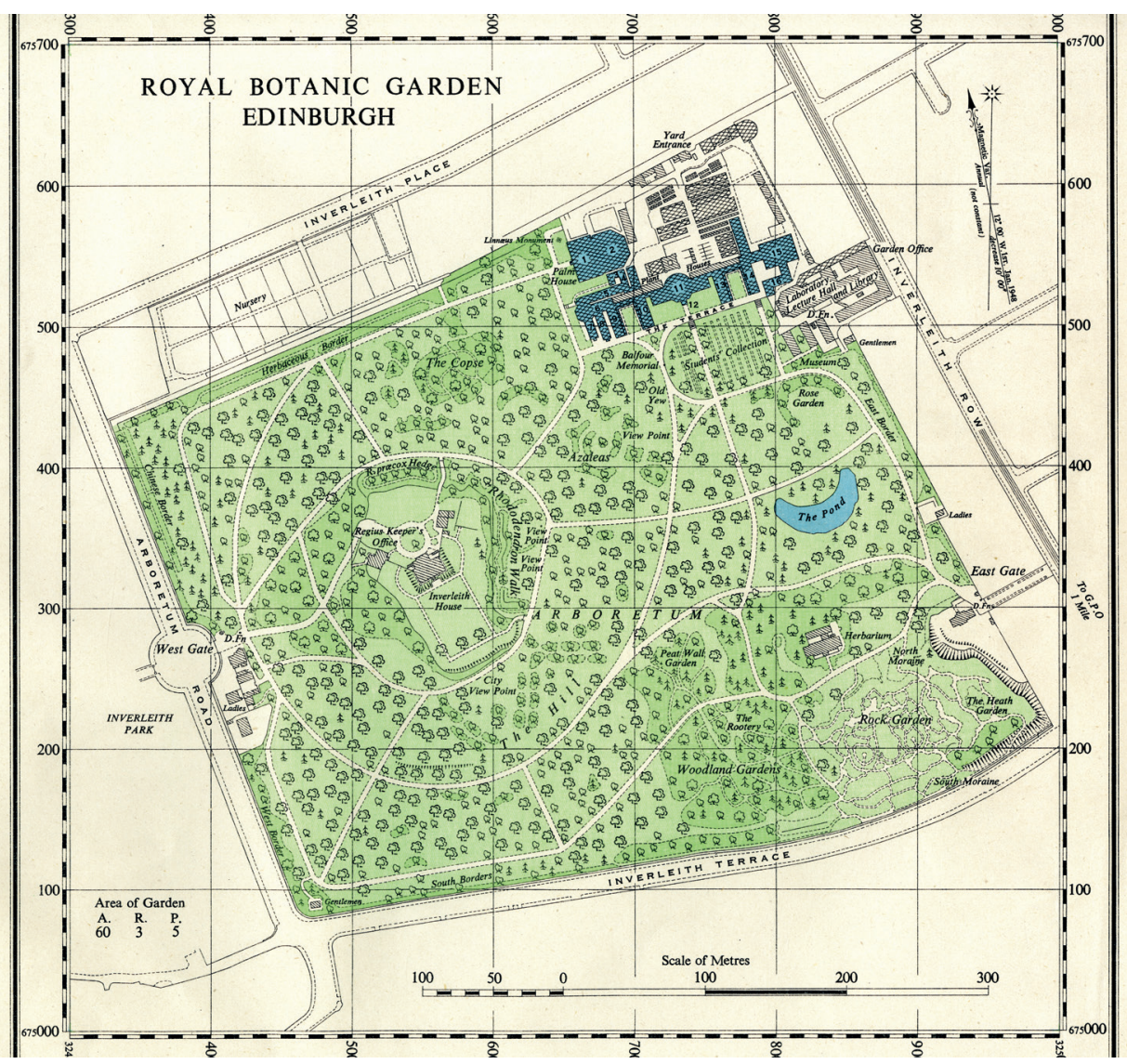

Fig. 17 Ordnance Survey map of RBGE, 1958. 


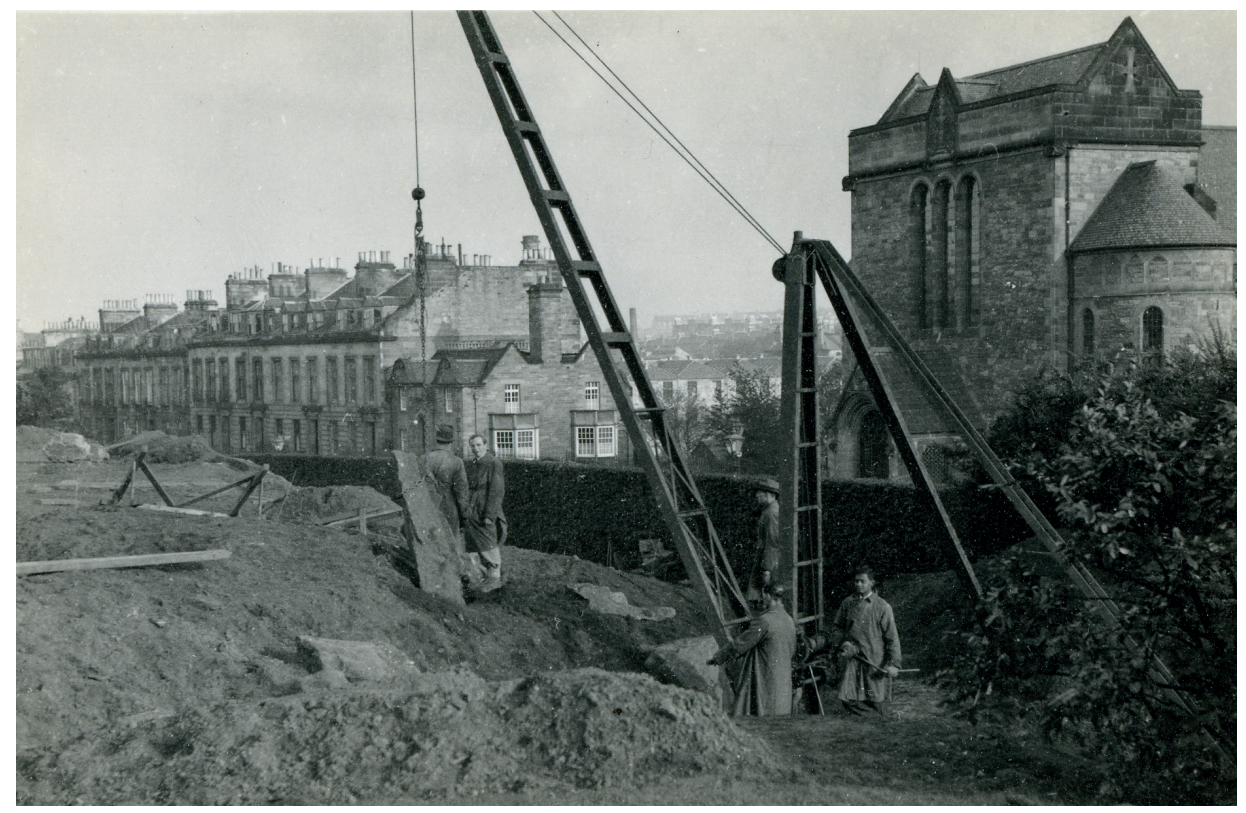

Fig. 18 Construction of the South Moraine, c. 1937. Image: RBGE Archives.

\section{RECENT HISTORY OF THE ROCK GARDEN}

Since the major redevelopment and enlargement of the Rock Garden in the time of Isaac Bailey Balfour, the hard landscape of the area has remained largely unchanged. The rock work being manoeuvred into place in Fig. 13 still provides the backbone of much of the area. The Rock Garden remains home to the bulk of the RBGE Living Collection of alpine plants from all over the world, just as it was in McNab's time. The most notable addition was the creation of the ponds in the 1960s and the waterfall in 1999 (Mitchell, 2006). Few of the plants remain from the time of Bayley Balfour but a notable exception is a large Poncirus trifoliata which dates to 1902.

The Rock Garden today is home to 3,154 accessions of plants, some of which can be ephemeral while others survive for many decades. Many of the dwarf rhododendron species on the west side of the Rock Garden were collected by those prolific collectors of the early 20th century, George Forrest, Frank Kingdon-Ward, Joseph Rock and Reginald Farrer. Collection of wild origin plants is essential for the vitality of a botanic garden collection and RBGE staff have continued to collect alpines and other taxa suitable for cultivation in the Rock Garden. These include horticulturists and botanists such as Richard Brown, Peter Davis, Martin Gardner, Ron McBeath, John Mitchell and Robert Unwin. 


\section{REFERENCES}

ANON. (1869). Editorial. The Gardeners' Chronicle and Agricultural Gazette. 365.

BUXTON, A. (2012). Royal Caledonian Horticultural Society, History, an overview. Available online: www.rchs.co.uk/about-us/history (accessed May 2015).

BUXTON, A. \& WOODS, J. (2009) Royal Caledonian Horticultural Society 1809-2009 (pamphlet). Royal Caledonian Horticultural Society, Edinburgh.

COWELY, H. (1915). The economy of rock work. The Garden; an illustrated weekly journal of gardening in all its branches 79: 386-387.

CUBEY, R., GARDNER, M., HUGHES, K., INCHES, F., KNOTT, D., RAE, D. \& THOMPSON, H. (2012). Catalogue of Plants 2012. Royal Botanic Garden Edinburgh, Edinburgh.

EDINA (1912). The 'Rock Garden' at Edinburgh. The Garden; an illustrated weekly journal of gardening in all its branches 76: 167.

FARRER, R. (1907). My Rock Garden. Arnold, London.

FLETCHER, H.R. \& BROWN, W.H. (1970). The Royal Botanic Garden Edinburgh 1670-1970. Her Majesty's Stationery Office, Edinburgh.

HARDY, G. "To get those plants ... likely to prove interesting at Edinburgh": Robert Brown of Perth and James McNab's North American Tour of 1834. Sibbaldia 9: 191-211.

HOBSON, A. (1992). Reginald Farrer of Clapham. North Craven Heritage Trust Journal. Available online: http://www.northcravenheritage.org.uk/nchtjournal/Journals/1992/J92A13. html (accessed July 2015).

LEICHTLIN, M. (1882). Botanical gardens. The Garden; an illustrated weekly journal of gardening in all its branches 22: 380-381.

MCNAB, J. (1871). A plea for rock gardens. The Garden; an illustrated weekly journal of gardening in all its branches 1: 70-71.

MCNAB, J. (1878). Stone ledges for rock gardens. The Garden; an illustrated weekly journal of gardening in all its branches 13: 514.

MISCELLANEOUS (1848). The Gardeners' Chronicle and Agricultural Gazette. 55.

MITCHELL, J. (2006). History and development of the Rock Garden. In: RAE, D., CUBEY, R., GARDNER, M., LATTA, J. \& WALTER, K. (eds). Catalogue of Plants 2006. Royal Botanic Garden Edinburgh, Edinburgh.

MUNRO, R. (1882). The Edinburgh Rock Garden. The Garden; an illustrated weekly journal of gardening in all its branches 22: 23 .

NATIONAL LIBRARIES OF SCOTLAND (1849-1853). Available online: http://maps.nls.uk/ view/74415414 (accessed May 2014).

NATIONAL LIBRARIES OF SCOTLAND (1877). Available online: http://maps.nls.uk/ view/74415629 (accessed May 2014).

PATERSON, L. (2013). How the Garden Grew, A Photographic History of Horticulture at $R B G E$. Royal Botanic Garden Edinburgh, Edinburgh.

RAE, D. (2011). The Living Collection. Royal Botanic Garden Edinburgh, Edinburgh. 
ROYAL BOTANIC GARDEN EDINBURGH (1934). A Brief Descriptive and Illustrated Account. His Majesty's Stationery Office, Edinburgh.

ROYAL BOTANIC GARDEN EDINBURGH (1970). The Garden Companion. Her Majesty's Stationery Office, Glasgow.

ROYAL CALEDONIAN HORTICULTURE SOCIETY (2014). History. Available online: www. rchs.co.uk/about-us/history (accessed May 2014).

SHULMAN, N. (2002). A Rage for Rock Gardening. St Edmundsbury Press, Bury St Edmunds.

'TRAVELLER' (1882). The Garden: an illustrated weekly journal of gardening in all its branches 22: 294.

WHITE, A. (1870). The Edinburgh Evening Courant. 18 April 1870. 
